Keywords: $M C U, S W P F, I S D P$

Retention: Permanent

\title{
Results of the Extraction-Scrub-Strip Testing Using an Improved Solvent Formulation and Salt Waste Processing Facility Simulated Waste
}

T. B. Peters

A. L. Washington II

S. D. Fink

January 2012

Savannah River National Laboratory Savannah River Nuclear Solutions Aiken, SC 29808

Prepared for the U.S. Department of Energy under

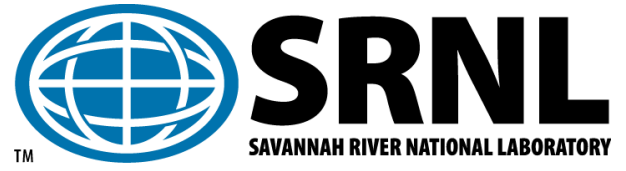
contract number DE-AC09-08SR22470. 
SRNL-STI-2011-00689

Revision 0

\section{DISCLAIMER}

This work was prepared under an agreement with and funded by the U.S. Government. Neither the U.S. Government or its employees, nor any of its contractors, subcontractors or their employees, makes any express or implied:

1. warranty or assumes any legal liability for the accuracy, completeness, or for the use or results of such use of any information, product, or process disclosed; or

2. representation that such use or results of such use would not infringe privately owned rights; or

3. endorsement or recommendation of any specifically identified commercial product, process, or service.

Any views and opinions of authors expressed in this work do not necessarily state or reflect those of the United States Government, or its contractors, or subcontractors.

\section{Printed in the United States of America}

Prepared for

U.S. Department of Energy 


\section{REVIEWS AND APPROVALS}

\section{AUTHORS:}

T. B. Peters, Author, SRNL/SASP

Date

A. L. Washington II, Co-author, SRNL/AC\&P

Date

TECHNICAL REVIEW:

C. A. Nash, Technical Reviewer, SRNL/AC\&P

Date

APPROVAL:

S. D. Fink, SRNL/SASP, Manager

Date

S. L. Marra, SRNL/E\&CPT Research Programs, Manager

Date 


\section{EXECUTIVE SUMMARY}

The Office of Waste Processing, within the Office of Technology Innovation and Development, is funding the development of an enhanced solvent - also known as the next generation solvent (NGS)- for deployment at the Savannah River Site to remove cesium from High Level Waste. The technical effort is a collaborative effort between Oak Ridge National Laboratory (ORNL) and Savannah River National Laboratory (SRNL). As part of the program, the Savannah River National Laboratory (SRNL) has performed a number of Extraction-Scrub-Strip (ESS) tests. These batch contact tests serve as first indicators of the cesium mass transfer solvent performance with actual or simulated waste. The test detailed in this report used simulated Tank $49 \mathrm{H}$ material, with the addition of extra potassium. The potassium was added at $1677 \mathrm{mg} / \mathrm{L}$, the maximum projected (i.e., a worst case feed scenario) value for the Salt Waste Processing Facility (SWPF).

The results of the test gave favorable results given that the potassium concentration was elevated $(1677 \mathrm{mg} / \mathrm{L}$ compared to the current $513 \mathrm{mg} / \mathrm{L})$. The cesium distribution value, $\mathrm{D}_{\mathrm{Cs}}$, for extraction was 57.1. As a comparison, a typical $\mathrm{D}_{\mathrm{Cs}}$ in an ESS test, using the baseline solvent formulation and the typical waste feed, is $\sim 15$. 


\section{LIST OF ABBREVIATIONS}

CSSX - Caustic-Side Solvent Extraction

DWPF - Defense Waste Processing Facility

ESS - extraction-scrub-strip

ICPMS - Inductively Coupled Plasma Mass Spectroscopy

ISDP - Integrated Salt Disposition Project

MCU - Modular Caustic-side Solvent Extraction Unit

NGS - next generation solvent

ORNL - Oak Ridge National Laboratory

SRNL - Savannah River National Laboratory

SWPF - Salt Waste Processing Facility 
SRNL-STI-2011-00689

Revision 0

\subsection{Introduction}

The Modular Caustic Side Solvent Extraction Unit (MCU) uses the Caustic-Side Solvent Extraction (CSSX) process to remove cesium (Cs) from alkaline waste. This process involves the use of an organic extractant, BoBCalixC6, ${ }^{\Upsilon}$ in an organic matrix to selectively remove cesium from the caustic waste. The organic solvent mixture flows counter-current to the caustic aqueous waste stream within centrifugal contactors. After extracting the cesium, the loaded solvent is stripped of cesium by contact with dilute nitric acid and the cesium concentrate is transferred to the Defense Waste Processing Facility (DWPF), while the organic solvent is cleaned and recycled for further use. The Salt Waste Processing Facility (SWPF), under construction, will use the same process chemistry.

The Office of Waste Processing (EM-31) expressed an interest in investigating the further optimization of the organic solvent by replacing the BoBCalixC6 extractant with a more efficient extractant. ${ }^{1}$ This replacement should yield dividends in improving cesium removal from the caustic waste stream, and in the rate at which the caustic waste can be processed. To that end, EM-31 provided funding for both the Savannah River National Laboratory (SRNL) and the Oak Ridge National Laboratory (ORNL). SRNL wrote a Task Technical Quality and Assurance Plan for this work. ${ }^{2}$

As part of the envisioned testing regime, it was decided to perform an ESS test using a simulated waste that simulated a typical envisioned SWPF feed, but with added potassium to make the waste more challenging. Potassium interferes in the cesium removal, and its concentration is limited in the feed to $<1950 \mathrm{mg} / \mathrm{L}$. The feed to MCU has typically contained $<500 \mathrm{mg} / \mathrm{L}$ of potassium.

\subsection{Experimental Procedure}

\subsection{Solvent Preparation}

ORNL provided the recipe for the improved solvent formulation, also known as the Next Generation Solvent (NGS). ${ }^{3}$ SRNL prepared a batch of this solvent. ${ }^{\perp}$ The MAXCalix $\operatorname{extractant}^{\Sigma}$ and Modifier ${ }^{f}$ were obtained from Marshallton Research Laboratories. The Isopar L TM was purchased from Exxon-Mobil. A sample of the suppressor ${ }^{\Re}$ was graciously donated by Cognis.

\footnotetext{
${ }^{\Upsilon}$ BoBCalixC6 stands for calix[4] arene-bis-(tert-octylbenzo)-crown-6

${ }^{\perp}$ The prepared solvent was from preparation\#2, 12/14/2010.

$\Sigma$ The extractant, MAXCalix, stands for 1,3-alt-25,27-Bis(3,7-dimethyloctyloxy)calix[4]arenebenzocrown-6

${ }^{f}$ Modifier stands for_1-(2,2,3,3,-Tetrafluoropropoxy)-3-(4-sec-butylphenoxy)-2-propanol

${ }^{\Re}$ The suppressor is a derivitized guanidine, N, N'-cyclohexyl, N' '-tridecyl guanidine
} 
The recipe for the new solvent formulation is given in Table 1.

Table 1. Material Additions for the Improved Solvent

\begin{tabular}{|c|c|}
\hline Chemical & Added Mass (g) \\
\hline MAXCalix & 4.81 \\
\hline Modifier & 17.0 \\
\hline Suppressor & 0.121 \\
\hline Isopar L TM & 62.1 \\
\hline
\end{tabular}

The prepared solvent had a measured density of $0.834 \mathrm{~g} / \mathrm{mL}$. Density results typically have a percentage standard deviation of $<1 \%$ between trials.

\subsection{Simulant Feed Makeup and Compositions}

The simulant chemically approximated the waste from Tank $49 \mathrm{H}$ with the exception of minor metal and organic compounds. The purpose of the simulant was to provide nonradioactive feed for quantifying cesium removal. A 41-liter batch of the simulant was prepared as part of another test program. ${ }^{4}$ Once prepared, $120 \mathrm{~mL}$ of this solution was removed for this work. Enough potassium was added to generate a final potassium concentration of $1677 \mathrm{mg} / \mathrm{L}$. Calculated concentrations of the primary components are listed in Table 2.

Table 2. Composition of Tank 49H Simulated Waste Solutions

\begin{tabular}{|c|c|c|c|}
\hline Component & Concentration (M) & Component & Concentration (M) \\
\hline $\mathrm{Na}^{+}$ & 6.5 & $\mathrm{CO}_{3}{ }^{2-}$ & 0.25 \\
\hline $\mathrm{K}^{+}$ & 0.043 & $\mathrm{SO}_{4}{ }^{2-}$ & 0.057 \\
\hline $\mathrm{Cs}^{+}$ & 0.00062 & $\mathrm{Cl}^{-}$ & 0.00062 \\
\hline $\mathrm{OH}^{-}$ & 2.65 & $\mathrm{PO}_{4}{ }^{3-}$ & 0.0047 \\
\hline $\mathrm{NO}_{3}{ }^{-}$ & 2.30 & $\mathrm{C}_{2} \mathrm{O}_{4}{ }^{2-}$ & 0.0013 \\
\hline $\mathrm{NO}_{2}{ }^{-}$ & 0.65 & $\mathrm{SiO}_{3}{ }^{2-}$ & 0.0046 \\
\hline $\mathrm{AlO}_{2}{ }^{-}$ & 0.19 & $\mathrm{COOH}^{-}$ & 0.021 \\
\hline
\end{tabular}

The analytical uncertainty on the measurements is $10 \%$. 


\subsection{ESS Testing}

For these tests, we used a nominal starting volume of $120 \mathrm{~mL}$ of aqueous feed, and $30 \mathrm{~mL}$ of fresh, unused NGS.

\subsection{Results and Discussion}

\section{$\underline{3.1 \text { ESS Testing }}$}

For the ESS tests, we followed the same protocol established for recent work. ${ }^{5,6}$ The ESS test is a series of organic (solvent)-aqueous (Tank $49 \mathrm{H}$ simulant) contacts. There are two extraction steps, two scrub steps, and three strip steps. Between each step we separate the phases, remove a portion of each phase for analysis, and place one of the phases back in the funnel and contact it with a new organic or aqueous phase (Table 3). The two phases are allowed to contact for $\sim 24$ hours before proceeding to the next step.

Table 3. ESS Test Steps

\begin{tabular}{|c|c|c|c|}
\hline Step \# & Type & $\begin{array}{c}\text { Nominal } \\
\text { Volume } \\
\text { ORGANIC }\end{array}$ & $\begin{array}{c}\text { Nominal } \\
\text { Volume } \\
\text { AQUEOUS }\end{array}$ \\
\hline 1 & Extraction \#1 & $30 \mathrm{~mL}$ & $120 \mathrm{~mL}$ \\
\hline 2 & Scrub \#1 & $30 \mathrm{~mL}$ & $8 \mathrm{~mL}$ \\
\hline 3 & Scrub \#2 & $30 \mathrm{~mL}$ & $8 \mathrm{~mL}$ \\
\hline 4 & Strip \#1 & $30 \mathrm{~mL}$ & $8 \mathrm{~mL}$ \\
\hline 5 & Strip \#2 & $30 \mathrm{~mL}$ & $8 \mathrm{~mL}$ \\
\hline 6 & Strip \#3 & $30 \mathrm{~mL}$ & $8 \mathrm{~mL}$ \\
\hline 7 & Extraction \#2 & $30 \mathrm{~mL}$ & $120 \mathrm{~mL}$ \\
\hline
\end{tabular}

The scrub aqueous phase is $0.025 \mathrm{M}$ sodium hydroxide, and the strip aqueous phase is $0.01 \mathrm{M}$ boric acid. Note that the scrub and strip solutions are different for the NGS than for the current solvent blend.

The Cs content for each phase in each step is measured by Inductively Coupled Plasma Mass Spectroscopy (ICPMS, with 20\% analytical uncertainty). Once corrected for operating temperature ${ }^{7}$-- each step has its own temperature correction factor -- the distribution values are calculated. The distribution factor, $\mathrm{D}_{\mathrm{Cs}}$, for any particular step is equal to the Cs concentration in the organic phase divided by the Cs concentration activity in the aqueous phase. For comparative purposes, we present the data from this test and from a previous baseline test that was performed under identical conditions, with the exception that the aqueous phase only had a potassium concentration of $507 \mathrm{mg} / \mathrm{L}$.

See Table 4 for the results of both tests. 
SRNL-STI-2011-00689

Revision 0

Table 4. Cesium Distribution Values for the ESS Tests

\begin{tabular}{|c|c|c|c|c|c|c|c|}
\hline Material & Extr \#1 & Extr \#2 & Scrub \#1 & Scrub \#2 & Strip \#1 & Strip \#2 & Strip \#3 \\
\hline $\begin{array}{c}\text { Acceptable } \\
\text { Range, } \\
\text { NGS }\end{array}$ & $\geq 60$ & NA & $\sim 2-4$ & $\sim 1-2.5$ & $\leq 0.33$ & $\leq 0.007$ & $\leq 0.003$ \\
\hline $\begin{array}{c}\text { NGS vs. Tank } \\
\text { 49H simulant }\end{array}$ & 80.6 & 59.0 & 3.63 & 1.13 & 0.00947 & 0.00235 & 0.337 \\
\hline $\begin{array}{c}\text { NGS vs. Tank } \\
49 H \text { simulant, } \\
1677 \text { mg/L K }\end{array}$ & 57.1 & 43.9 & 5.14 & 1.26 & 0.0158 & 0.00376 & 0.0865 \\
\hline
\end{tabular}

High distribution values in the extraction steps are important as they indicate transference of Cs from the aqueous phase into the organic phase. Low values are important in the strip steps as they indicate successful removal of the cesium. The scrub values should show moderate values indicating not much transfer in either direction.

Both tests show excellent extraction results compared to what is currently used as the acceptable range of results, and both show the same trends. Scrub $\# 1 \mathrm{D}_{\mathrm{Cs}}$ results are high, as is typical with the NGS results. ${ }^{8,9,10}$ Strip \#1 and \#2 values are also quite good and within the acceptable range. Strip \#3 values tend to run higher than Strip \#2 values. This has occurred in every test involving the use of MAXCalix. An expected pH of 5.5 was found for the Strip \#3 sample. This indicates very little caustic carryover from the original aqueous phase, or scrub caustic $(0.025 \mathrm{M} \mathrm{NaOH})$ carryover. A check of the cesium results indicates that we are far enough from the instrument detection limits so that the uncertainties are acceptable.

Given the similarities in the Strip \#3 results for the MAXCalix ESS tests, SRNL considers it possible that the high Strip \#3 values are indicative of something in the process chemistry is occurring and not a failure in the execution of the experiment. SRNL will be examining different aspects of the ESS testing (such as the fate of the suppressor) in order to determine if the chemistry of the testing requires adjustments.

\subsection{Conclusions}

This test clearly demonstrates that the improved solvent yielded substantially superior extraction and strip behavior compared to the baseline solvent, and in the face of a large excess of potassium, a known interfering agent. 
SRNL-STI-2011-00689

Revision 0

\subsection{References}

${ }^{1}$ Project\# HQTD1002, WP-2.1.6, "Next Generation Cesium Solvent"

2 T. B. Peters and S. D. Fink, "Task Technical and Quality Assurance Plan For Studies of Improved CSSX Solvent Formulations", SRNL-RP-2010-01028, Rev 1, August 2010.

${ }^{3}$ B. A. Moyer, "Initial NG-CSSX Solvent Recommendation," letter to N. P. Machara, June 30, 2010.

${ }^{4}$ R. A. Pierce, T. B. Peters, M. L. Crowder, T. D. Caldwell, D. J. Pak, S. D. Fink, R. W. Blessing, and A. L. Washington, "Demonstration of the Next-Generation Caustic-Side Solvent Extraction Solvent with 2-cm Centrifugal Contactors using Tank 49H Waste and Waste Simulant", SRNL-STI-2011-00589, September 2011.

${ }^{5}$ T. B. Peters and S. D. Fink, "Results from Monosodium Titanate (MST) and Extraction-Scrub-Strip (ESS) Testing of ISDP Macrobatch 3 Blend", SRNL-STI-2010-00290, May 2010.

${ }^{6}$ T. B. Peters, C. A. Nash, and S. D. Fink, "ISDP Salt Batch \#2 Supernate Qualification”, SRNL-STI-200800446, Rev. 1, January 5, 2009.

${ }^{7}$ B. A. Moyer, N. J. Williams, "Temperature Dependence of the Next Generation Caustic Side Solvent Extraction (NG-CSSX) Process Solvent", ORNL-LTR-NGCSSX-012, August 5, 2011.

${ }^{8}$ T. B. Peters and S. D. Fink, "Results of First Extraction-Scrub-Strip Testing using Improved Solvent Formulations and Actual Savannah River Site Waste", SRNL-STI-2010-00586, September 2010.

${ }^{9}$ T. B. Peters and S. D. Fink, "Results of the Third Extraction-Scrub-Strip Real Waste Test Using An improved Solvent Formulation", SRNL-STI-2010-00803, March 2011.

${ }^{10}$ T. B. Peters, A. L. Washington II and S. D. Fink, "Results of Cesium Mass Transfer Testing for Next Generation Solvent with Hanford Waste Simulant AP-101, SRNL-STI-2011-00559, September 2011. 


\section{Distribution:}
A. B. Barnes, 999-W
S. D. Fink, 773-A
B. J. Giddings, 786-5A
C. C. Herman, 999-W
S. L. Marra, 773-A
F. M. Pennebaker, 773-42A
J. C. Griffin, 773-A
A. P. Fellinger, 773-41A
W. R. Wilmarth, 773-A
E. J. Freed, 704-56H
D. J. Martin, 241-152H
M. W. Geeting, 241-152H
S. J. Brown, 241-152H
S. G. Campbell, 992-5W
B. A. Gifford, 704-56H

T.B. Peters, 773-42A

C. A. Nash, 773-42A

M. R. Poirier, 773-42A

F. F. Fondeur, 773-A

S. A. Thomas, 703-46A

N. P. Machara

B. A. Moyer, ORNL

L. H. Delmau, ORNL

W. B. Brasel, 992-2W

C. Conner, Parsons

R. D. Lentsch, Parsons

M. S. Brugh, Parsons

T. D. Burns, Parsons

A. N. Singer, Parsons

M. J. Thomas, Parsons

R. J. Schepens, Parsons

R. K. Leugemors, 992-5W

P. G. Suggs, 704-S

P. Jackson, 703-46A 